\title{
Field work in central and northern East Greenland
}

\section{Agnete Steenfelt}

The expedition to central and northern East Greenland in 1975 had 29 participants. Ten of these took part in the programme for uranium prospecting (Steenfelt, and Secher $e t$ al., this report) and 5 field teams studied the following subjects: the sedimentology of continental Trias in Scoresby Land (Clemmensen \& Andreasen, this report), the stratigraphy and structure of the lower Eleonore Bay Group sediments in the Alpefjord region (Caby, this report), the geochemistry of heavy metals in the Eleonore Bay Group, the Caledonian crystalline complex in relation to older crystalline rocks (Frederichsen \& Higgins, this report), and finally the Quaternary deposits around Clavering $\emptyset$.

The field parties and the prospecting work were served by a helicopter chartered from Heliswiss, Berne, and by the GGU cutter Jytte. The base camp for all operations was at Stordal situated in Muskusoksefjord, west of Hold with Hope. Personnel were flown from Copenhagen via Iceland, to Mesters Vig from where the $200 \mathrm{~km}$ journey to Stordal was carried out by a Beechcraft chartered from Flugfélag Norðurlands, Iceland.

The expedition activity is to continue in $\mathbf{1 9 7 6 .}$

\section{Reconnaissance work in the crystalline complexes of northern East Greenland between $72^{\circ}$ and $74^{\circ} \mathrm{N}$}

\section{J. D. Friderichsen and A. K. Higgins}

Most crystalline rocks of northern East Greenland have until recently been regarded as representing the deep-seated mobile core zone of the Caledonian orogenic belt (Haller, 1971). However, recent regional mapping and isotopic studies in the Scoresby Sund region indicate that the main development of the crystalline complexes relate to Archaean and Proterozoic orogenesis, with a relatively superficial Caledonian overprint (Henriksen \& Higgins, 1976). It was a logical step to extend field studies northwards to the crystalline rocks of the region between $72-74^{\circ} \mathrm{N}$ (fig. 32). These studies supplement isotopic work in progress on material from the crystalline complexes collected by D. C. Rex (Leeds) in 1974 (Rex et al., this report), as well as the research being carried out on various aspects of the Eleonore Bay Group by R. Caby (Montpellier) this report and H. Stendal (Copenhagen).

As 1:250 000 geological maps of the region north of $72^{\circ} \mathrm{N}$ already exist (Koch \& Haller, 1971), detailed mapping was carried out only in a few critical areas. Attention was given to crystalline units which might have similarities with those of the Scoresby Sund region, including the three main infracrustal complexes (Gletscherland migmatite complex, Niggli Spids migmatite dome, Hagar migmatite sheet) which have usually been regarded as deep- 